\section{Helicobacter pylori cagE is not associated with clinical outcomes in the Kurdistan region of Iraq}

\section{Nawfal R. Hussein ${ }^{[1]}$ and Rawand Al-Qadi ${ }^{[2]}$}

[1]. Department of Internal Medicine, School of Medicine, Faculty of Medical Sciences, Duhok, Kurdistan region, Iraq. [2]. Molecular Department, Central Public Health Laboratory, Duhok, Kurdistan Region, Iraq.

\section{Dear Editor,}

We have read with interest the article entitled "cagE as a biomarker of the pathogenicity of Helicobacter pylori" by Ramis et al. ${ }^{1}$. In this study, with a sample size of 57 , the authors suggested that $\operatorname{cag} E$ is an important prognostic indicator for developing lesions during Helicobacter pylori infection. This suggestion was based on the fact that a statistically significant association was found between $\operatorname{cag} E$ and gastric erosion, but not between cagA and gastric erosion.

With reference to this study, we conducted a study in the Kurdistan region of Iraq to examine relationships between H. pylori virulence factors and clinical outcomes. Antral Biopsies were collected from 105 patients visiting the Endoscopy Department at the Azadi Teaching Hospital for diagnostic upper gastric endoscopy. Deoxyribonucleic acid (DNA) was extracted directly from the biopsy samples, and the presence of $H$. pylori was confirmed by polymerase chain reaction (PCR) amplification of the ureA gene. We amplified the $\operatorname{cag} A, \operatorname{cag} E, \operatorname{vac} A s 1 / \mathrm{m} 1, v a c A, i c e A 1, i c e A 2$, and $b a b A 2$ genes and found a statistically significant association between $\operatorname{cag} A$ and gastric and duodenal ulcerations ( $p=0.005)$, but no statistically significant association between $\operatorname{cag} E$ and gastric and duodenal ulcerations $(p=0.659)$. In addition, no association was found between other genes and clinical outcomes.

cagA is a part of a $40-\mathrm{kb}$ DNA insertion cassette designated as the cag pathogenicity island (cagPAI), which may have a nonHelicobacter origin. The cagPAI contains 31 putative genes, 6 of which are thought to encode components of a bacterial type IV secretion system. cagE, is a homolog of the virB4 gene from Agrobacterium tumefaciens $^{2}$ and also is a part of the cagPAI region of Helicobacter pylori genome. The presence of cagE is essential for the formation of type IV secretion system.

Recent studies have indicated that the cagA protein is directly injected into epithelial cells via the type IV secretion system, where it undergoes tyrosine phosphorylation in host cells $^{3}$. The presence of cag $A$ has been considered as an important predictor for the severity of the pathogenicity of $H$. pylori, on the other hand the role of $\operatorname{cag} E$ as a marker of the disease is still to be contemplated, as shown by the data from our study. The contradiction in the results of our study and that of Ramis et al. may be due to differences in the respective study designs and sample sizes. Therefore, a large cross-sectional study involving multi-centers with different populations should be designed to study the association between virulence factors and clinical outcomes. In addition, such a contradiction should not discourage small, national, cross-sectional association studies, because such studies may help suggest new determinants as virulence factors specific for $H$. pylori infections. In addition to the presence of cagA and cagE, empty-site PCR is also suggested to confirm the presence of $\operatorname{cag}$ PAI. Finally, we believe that none of the $H$. pylori virulence factors should be considered as predictors for $H$. pylori-related pathogenesis without studying other effects e.g. the host polymorphisms in genes responsible for inflammation and protection against oxidative stress, also genes involved in metabolism of drugs used in eradication of H. pylori, and environmental factors ${ }^{4}$.

\section{CONFLICT OF INTEREST}

The author declare that there is no conflict of interest.

\section{REFERENCES}

1. Ramis IB, Vianna JS, Silva Junior LV, Von Groll A, Silva PE. cagE as a biomarker of the pathogenicity of Helicobacter pylori. Rev Soc Bras Med Trop 2013; 46:185-189.

2. Censini S, Lange C, Xiang Z, Crabtree JE, Ghiara P, Borodovsky M, Rappuoli R, Covacci A. cag, a pathogenicity island of Helicobacter pylori, encodes type I-specific and disease-associated virulence factors. Proc Natl Acad Sci USA 1996; 93:14648-14653.

3. Atherton JC. The pathogenesis of Helicobacter pylori-induced gastroduodenal diseases. Annu Rev Pathol 2006; 1:63-96.

4. Izzotti A, Durando P, Ansaldi F, Gianiorio F, Pulliero A. Interaction between Helicobacter pylori, diet, and genetic polymorphisms as related to non-cancer diseases. Mutat Res 2009; 667:142-157.

Address to: Dr. Rawand Al-Qadi. Molecular Department/Central Public Health Laboratory. 2 Sargalo Street, Duhok 48001 Kurdistan region, Iraq.

Phone: 0096475 0480-7592

e-mail: raqrawi@yahoo.com

Received 12 November 2013

Accepted 22 January 2014 